\title{
Hydrologic Effects of Well-Field Operations in a Wetland, Dade County, Florida
}

By Roy S. Sonenshein, U.S. Geological Survey; and Ronald H. Hofstetter, University of Miami

U.S. GEOLOGICAL SURVEY

Water-Resources Investigations Report 90-4143

Prepared in cooperation with the

SOUTH FLORIDA WATER MANAGEMENT DISTRICT

and the

METRO-DADE WATER AND SEWER AUTHORITY 
U.S. DEPARTMENT OF THE INTERIOR

MANUEL LUJAN, JR., Secretary

U.S. GEOLOGICAL SURVEY

Dallas L. Peck, Director

For additional information write to:

District Chief

U.S. Geological Survey

Suite 3015

227 North Bronough Street

Tallahassee, Florida 32301
Copies of this report can be purchased from:

U.S. Geological Survey Books and Open-File Reports Federal Center, Building 810 Box 25425

Denver, Colorado 80225 


\title{
CONTENTS
}

\author{
Abstract 1 \\ Introduction 1 \\ Purpose and scope 3 \\ Description of study area 3 \\ Previous investigations 3 \\ Acknowledgments 3 \\ Data compilation and analysis $\mathbf{3}$ \\ Rainfall $\mathbf{3}$ \\ Rainfall-discharge relation 4 \\ Well-field pumpage 4 \\ Water-level trends 7 \\ Background conditions 7 \\ Wells outside the cone of depression 7 \\ Wells within the cone of depression 8 \\ Effects of pumping on water levels in the wetland 9 \\ Summary 15 \\ References cited 15
}

\section{FICURES}

1. Map of study area showing data-collection sites, section A-A', and region of wetlands dewatered by pumping 2

2-3. Graphs showing:

2. Monthly rainfall at Miami International Airport and mean daily pumpage by month from the Northwest Well Field, May 1983 to September 19875

3. Average monthly rainfall at Miami International Airport and average mean daily pumpage by month from the Northwest Well Field, January 1984 to September $1987 \quad 6$

4. Double-mass curve showing relation between cumulative rainfall at Miami International Airport and cumulative discharge in Tamiami Canal at Coral Gables, 1961 to 19877

5-8. Hydrographs of daily maximum water levels in observation wells:

5. G-968 and G-972, October 1960 to September 19878

6. G-975 and G-1488, October 1960 to September 19879

7. G-974 and G-976, October 1960 to September 198710

8. G-3253, December 1981 to September 198711

9-12. Water-level duration curves for:

9. Wells G-968 and G-972 12

10. Wells G-975 and G-1488 13

11. Wells G-974 and G-976 14

12. Well G-3253 15

13. Vertical profile along section $A-A^{\prime}$ showing water levels for April 1982, October 1982, October 1987, and April 198816

TABLE

1. Available ground-water level, surface-water stage and discharge, and rainfall data at data-collection sites in the study area 4 


\section{ABBREVIATIONS AND CONVERSION FACTORS}

The inch-pound units used in this report may be converted to metric (International System) units by the following factors:

\begin{tabular}{lcl}
\hline \multicolumn{1}{c}{ Multiply inch-pound unit } & By & To obtain metric unit \\
\hline & & millimeter $(\mathrm{mm})$ \\
inch (in.) & 25.4 & meter $(\mathrm{m})$ \\
foot (ft) & 0.3048 & kilometer $(\mathrm{km})$ \\
mile (mi) & 1.609 & square kilometer $\left(\mathrm{km}^{2}\right)$ \\
square mile $\left(\mathrm{mi}^{2}\right)$ & 2.590 & cubic meter per second $\left(\mathrm{m}^{3} / \mathrm{s}\right)$ \\
million gallons per day (Mgal $/ \mathrm{d})$ & 0.04381 & \\
\hline
\end{tabular}




\section{Hydrologic Effects of Well-Field Operations in a Wetland, Dade County, Florida}

\author{
By Roy S. Sonenshein and Ronald H. Hofstetter
}

\section{ABSTRACT}

Water-level, canal stage and discharge, and rainfall data collected in a wetland in Dade County, Florida, were analyzed to determine the effects of pumping at the Northwest Well Field on water levels in the wetland. The Northwest Well Field is the first major well field in south Florida to be operated in a wetland, away from saltwater intrusion and the potential for contamination caused by urbanization.

Duration curves were used to analyze trends in water levels for seven observation wells near the Northwest Well Field. One observation well is $\mathbf{5 . 5}$ miles north of the well field, three wells are outside the cone of depression of the well field, and three are within the cone of depression. The water-level data were analyzed for four time periods that were determined by a double-mass analysis of cumulative rainfall and cumulative canal discharge. Before 1984, water levels in all seven wells were above land surface 25 to 50 percent of the time. Since the well field began operating in 1984, water levels in the three wells within the cone of depression have been above land surface less than 1 percent of the time. Water levels at the four wells outside the cone of depression showed no effect from pumping at the well field.

Water levels have declined in 30 percent of the 65-square mile study area since the well field began operating. In 15 percent of the area, water levels have been lowered below land surface.

\section{INTRODUCTION}

The need to protect well fields from various land uses and the need to protect ecological systems are of utmost importance to Florida as well as to the Nation. One such ecological system, known for esthetic value in Dade County, Fla., are the wetlands. Concern has been raised by watermanagement officials and others about the hydrologic effects of operating a well field in a wetland in Dade County.

The hydrology of Dade County and of south Florida in general has been greatly affected by man's activities. The development of the area has been described previously by Parker and others (1955, p. 179-183) and Klein and others
(1975, p. 52-66). Before 1900, north-central Dade County was a wetland, part of the vast Everglades that covered most of south Florida. Initial drainage of the area was provided by the Miami Canal, completed in 1913. The Dade-Broward Levee, completed in 1927, was constructed to prevent overflow in The Everglades from moving eastward to developed areas of Dade County. The Tamiami Canal, completed in 1928, provided additional drainage of the area. The North Line, Dressels, and Snapper Creek Extension Canals were completed during the 1930's, providing additional flood protection in the areas to the east. Final flood protection was provided by Levee $30(\mathrm{~L}-30)$ and the L-30 Canal, completed in 1952. L-30 eliminated sheetflow to the study area from the rest of The Everglades. This resulted in the lowering of typical annual peak water levels east of the Dade-Broward Levee by about 1 foot (Labowski, 1988, p. 17) and storm peaks by 2 to 3 feet (Kohout and Hartwell, 1967, p. 26).

The completion of the Northwest Well Field in 1983 added to the changes in the hydrology of the study area. The well field, operated by the Metro-Dade Water and Sewer Authority (MDWSA), consists of 15 supply wells with a total capacity of $165 \mathrm{Mgal} / \mathrm{d}$ (fig. 1). These wells, spaced about 750 feet apart, are located on a 2-mile stretch about 2 miles west of the Snapper Creek Extension Canal and about 4.5 to 6.5 miles north of the Tamiami Canal (fig. 1). Each well is about 75-feet deep and is cased to a depth of 40 feet with 48-inch diameter steel casing.

The hydrologic effects of the Northwest Well Fieldthe first major well field operated in a wetland in south Florida-are of major interest because of the trend to move well fields inland, away from both the potential for saltwater intrusion and ground-water contamination caused by urbanization. Pumping from the Northwest Well Field has resulted in lowered water levels in the area. For this reason, the U.S. Geological Survey, in cooperation with the South Florida Water Management District and the Metro-Dade Water and Sewer Authority, began an investigation to delineate the area surrounding the Northwest Well Field in which water levels have been lowered and to assess the effects that pumping in this and in similar wetlands can have on the wetland environment. 


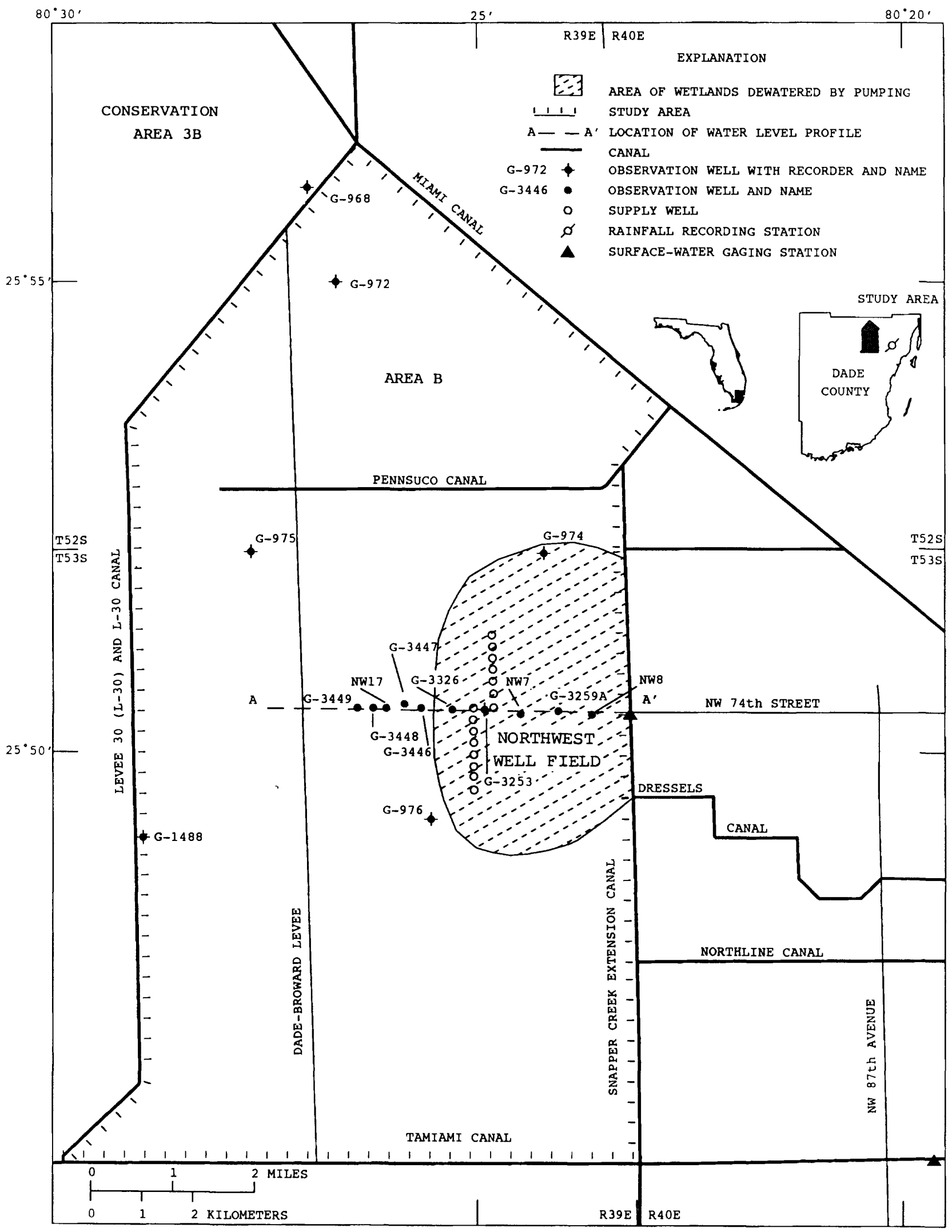

Figure 1. Study area showing data-collection sites, section $A-A^{\prime}$, and region of wetlands dewatered by pumping. 


\section{Purpose and Scope}

This report assesses the hydrologic effects of the operation of the Northwest Well Field on the surrounding wetland. It also describes the effects of water-management practices and of pumping from the Northwest Well Field on water levels in the well-field area, and documents changes in water levels caused by operations of the well field from 1984 to 1987. Rainfall and pumpage data were analyzed to determine any correlation, and statistical analyses of existing water-level data were used to determine any significant water-level changes. Water levels were measured periodically in a profile through the cone of depression at the well field to show variations in water level with time.

\section{Description of Study Area}

The Northwest Well Field lies within an area designated as the well-field protection zone, comprised mostly of undeveloped wetlands (Hofstetter and Sonenshein, 1990) and rock pits, encompassing about $65 \mathrm{mi}^{2}$. This area, referred to as the study area in this report, is bordered on the west and north by the L-30 Canal, on the south by the Tamiami Canal, on the east by the Snapper Creek Extension Canal, and on the north by the Miami Canal (fig. 1). This area is part of the region designated "Area B" by the U.S. Army Corps of Engineers (1954, p. 4).

Water from the Northwest Well Field, as with all municipal supply well fields in Dade County, is withdrawn from the unconfined Biscayne aquifer. In the vicinity of the well field, the aquifer is composed primarily of a very porous, sandy limestone with some interbedded sandstone (Causaras, 1987, sheet 1; Labowski, 1988, p. 5-8). The thickness of the Biscayne aquifer in the study area ranges from 70 to $90 \mathrm{feet}$, thickening to the east. Peat and muck overlie the entire study area, ranging from several inches to more than 5 feet in thickness (U.S. Army Corps of Engineers, 1954, pl. 5).

\section{Previous Investigations}

Regional hydrologic investigations (Parker and others, 1955, p. 179-183; Leach and others, 1972, p. 82-84) have included general analyses of the hydrology of the study area. Stallman (1956) and Kohout and Hartwell (1967) determined the effects of a proposed flood-control plan for the study area. As part of the flood-control study, Klein and Sherwood (1961) defined the aquifer characteristics in the vicinity of L-30. The hydrogeology of the Northwest Well Field protection zone was studied by Labowski (1988), and the hydrogeology of the surficial aquifer system for Dade County, which includes the Biscayne aquifer, was studied by
Fish and Stewart (1990). Hofstetter and Sonenshein (1990) used aerial photography to analyze vegetative changes in the study area between 1978 and 1986.

\section{Acknowledgments}

The authors thank the Metro-Dade Water and Sewer Authority for allowing the installation of hydrologic stations on their property and for providing well-field pumpage data. Appreciation is also extended to Isaac Sznol of the Dade County Department of Environmental Resources Management for providing information on water management and drainage practices in the study area.

\section{DATA COMPILATION AND ANALYSIS}

Water-level, surface-water stage and discharge, and rainfall data from previously existing recording stations were used in this investigation (table 1). Collection of continuous water-level data at five observation wells began in 1960 . Two additional observation wells were subsequently installed; one in 1970 and another in 1982 . The locations of all these wells are shown in figure 1 . In 1960, collection of continuous discharge data began at surface-water gaging station 02289500, Tamiami Canal near Coral Gables, southeast of the study area (fig. 1). Rainfall data from station 254800080180001 at Miami International Airport, 8 miles east of the well field and 2.5 miles east of the southeast corner of the study area (fig. 1), were obtained from the National Oceanic and Atmospheric Administration (1986).

Other data used for this investigation were well-field pumpages provided by the Metro-Dade Water and Sewer Authority (written commun., 1989) and miscellaneous waterlevel measurements. Water levels in a network of wells and at a surface-water gaging station along an east-west transect through the middle of the well field (fig. 1, profile A-A') were measured at the end of the wet season (October or November) and at the end of the dry season (April or May). These stations, listed in table 1, were installed after the well field became operational in 1984.

\section{Rainfall}

Rainfall follows a seasonal pattern in south Florida (figs. 2 and 3). The wet season, with approximately 70 percent of the average annual rainfall of 60 inches (Jordan, 1984 , p. 19, 22), occurs from May through October and the dry season is from November through April. Occasional winter and spring storms can often result in excessive rainfall amounts over brief periods of time during the dry season, as was the case in March 1986 (fig. 2). 
Table 1. Available ground-water level, surface-water stage and discharge, and rainfall data at data-collection sites in the study area

[Station name: NOAA, National Oceanic and Atmospheric Administration.

Type of site: $\quad$ GW, ground water; SW, surface water; RA, rainfall.

Type of data: $M X W L$, maximum daily water levels; MSWL, miscellaneous water levels;

$M D Q$, mean daily discharge; MDS, mean daily stage; $D R$, daily rainfall]

\begin{tabular}{ccccc}
\hline $\begin{array}{c}\text { Site } \\
\text { identification } \\
\text { number }\end{array}$ & Station name & $\begin{array}{c}\text { Type } \\
\text { of } \\
\text { site }\end{array}$ & $\begin{array}{c}\text { Type } \\
\text { of } \\
\text { data }\end{array}$ & $\begin{array}{c}\text { Beginning } \\
\text { year of data } \\
\text { collection }\end{array}$ \\
\hline 255600080270001 & G-968 & GW & MXWL & 1960 \\
255522080261401 & G-972 & GW & MXWL & 1960 \\
255207080241301 & G-974 & GW & MXWL & 1960 \\
255208080274001 & G-975 & GW & MXWL & 1960 \\
255023080202301 & G-976 & GW & MXWL & 1960 \\
254830080284201 & G-1488 & GW & MXWL & 1970 \\
255027080245501 & G-3253 & GW & MXWL & 1982 \\
255026080240302 & G-3259A & GW & MSWL & 1983 \\
255027080251801 & G-3326 & GW & MSWL & 1984 \\
255028080254001 & G-3446 & GW & MSWL & 1987 \\
255031080255201 & G-3447 & GW & MSWL & 1987 \\
255028080261401 & G-3448 & GW & MSWL & 1987 \\
255028080262501 & G-3449 & GW & MSWL & 1987 \\
255024080242901 & NW-7 & GW & MSWL & 1986 \\
255024080233901 & NW-8 & GW & MSWL & 1986 \\
255033080260201 & NW-17 & GW & MSWL & 1986 \\
02289500 & Tamiami Canal near Coral Gables & SW & MDQ & 1960 \\
255026080231300 & Snapper Creek Extension Canal at & SW & MDS & 1984 \\
& N.W. 74th Street & SW & & \\
254800080180001 & NOAA weather service measurement & RA & DR & 1984 \\
& Operation station no. 5663 at & RA & & \\
\hline & Miami International Airport & & & \\
\hline & & & & \\
\hline
\end{tabular}

\section{Rainfall-Discharge Relation}

A double-mass curve showing the relation between cumulative rainfall and cumulative discharge was used to determine possible changes in regional water-management practices. This type of analysis, described by Searcy and Hardison (1960), is an arithmetic plot of cumulative discharge against cumulative rainfall. Although this technique works best on uncontrolled rivers, it has also been used successfully on the controlled canals of south Florida by Leach and others (1972) and Klein and others (1975).

The double-mass curve of discharge of the Tamiami Canal at Coral Gables (station 02289500) against rainfall at Miami International Airport (fig. 4) shows breakpoints at 1970, 1977, and 1983 (fig. 4), signifying a change in the relation between discharge and rainfall. A change in slope toward the discharge axis indicates increased discharge for an equivalent amount of rainfall in subsequent years. The breaks in the curves at 1970 and 1977 are attributed to changes in water management of the canals in the study area. The break between 1983 and 1984 corresponds to the start of pumping at the well field. Ground-water pumpage reduces the amount of water discharged by the canal, thus, changing the slope of the curve toward the rainfall axis. The three time periods delineated by the breakpoints in the double-mass curve were used in the statistical analyses of the water-level data described in the next section.

\section{Well-Field Pumpage}

Pumpage from the Northwest Well Field has been relatively consistent year round although average daily pumpage is slightly higher during the period from March to August (fig. 3). Since January 1984, when the well field became fully operational, mean daily pumpage per month has ranged from 64 to $163 \mathrm{Mgal} / \mathrm{d}$ (fig. 2). The average daily pumpage for the period January 1984 to September 1987 was $134 \mathrm{Mgal} / \mathrm{d}$. The extreme low for November is an anomaly due to the few pumpage values available for this period and the fact that in both 1984 and 1985, the well field was not used during part of this month because of operational problems. 

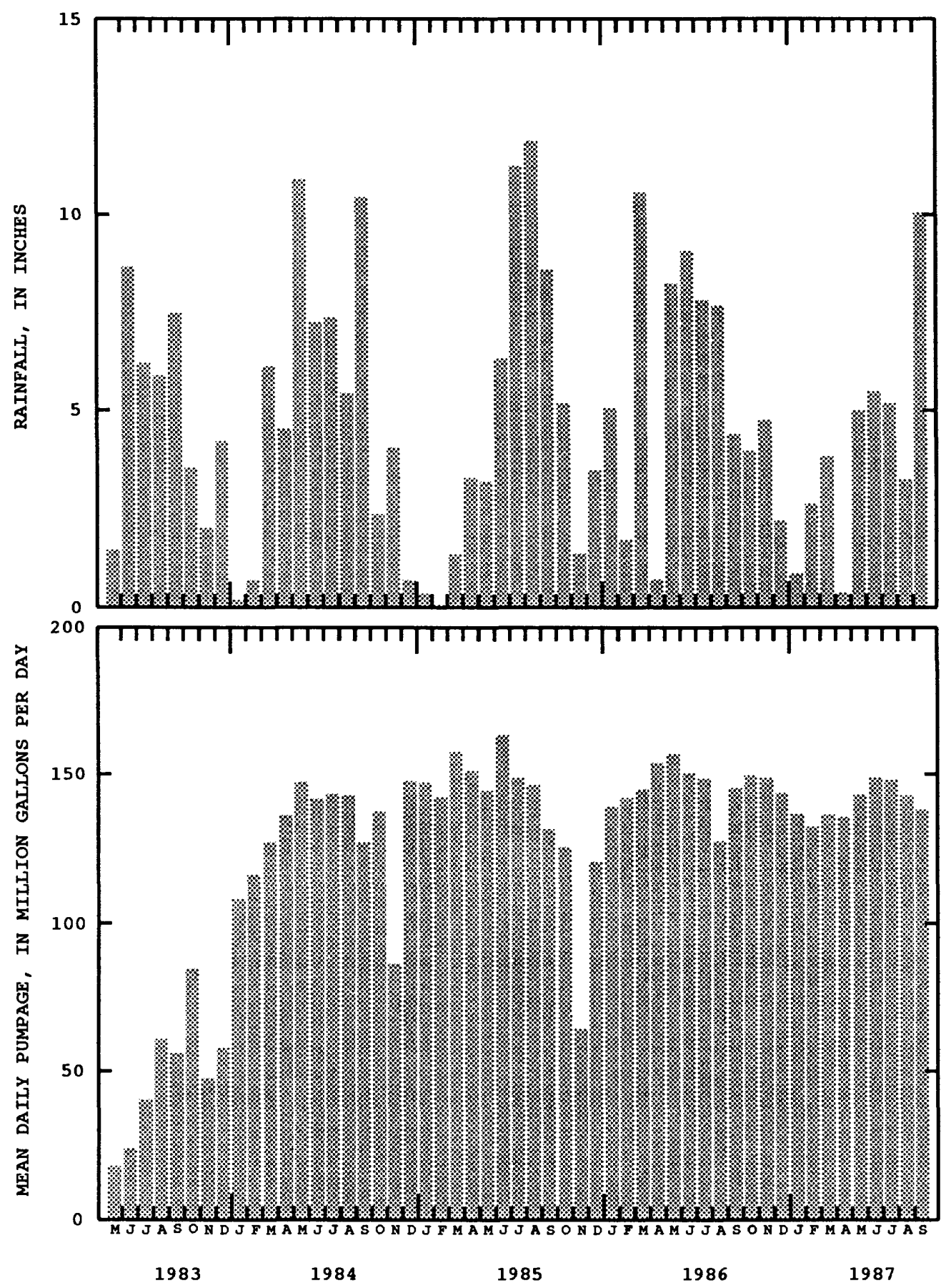

Figure 2. Monthly rainfall at Miami International Airport and mean daily pumpage by month from the Northwest Well Field, May 1983 to September 1987. 

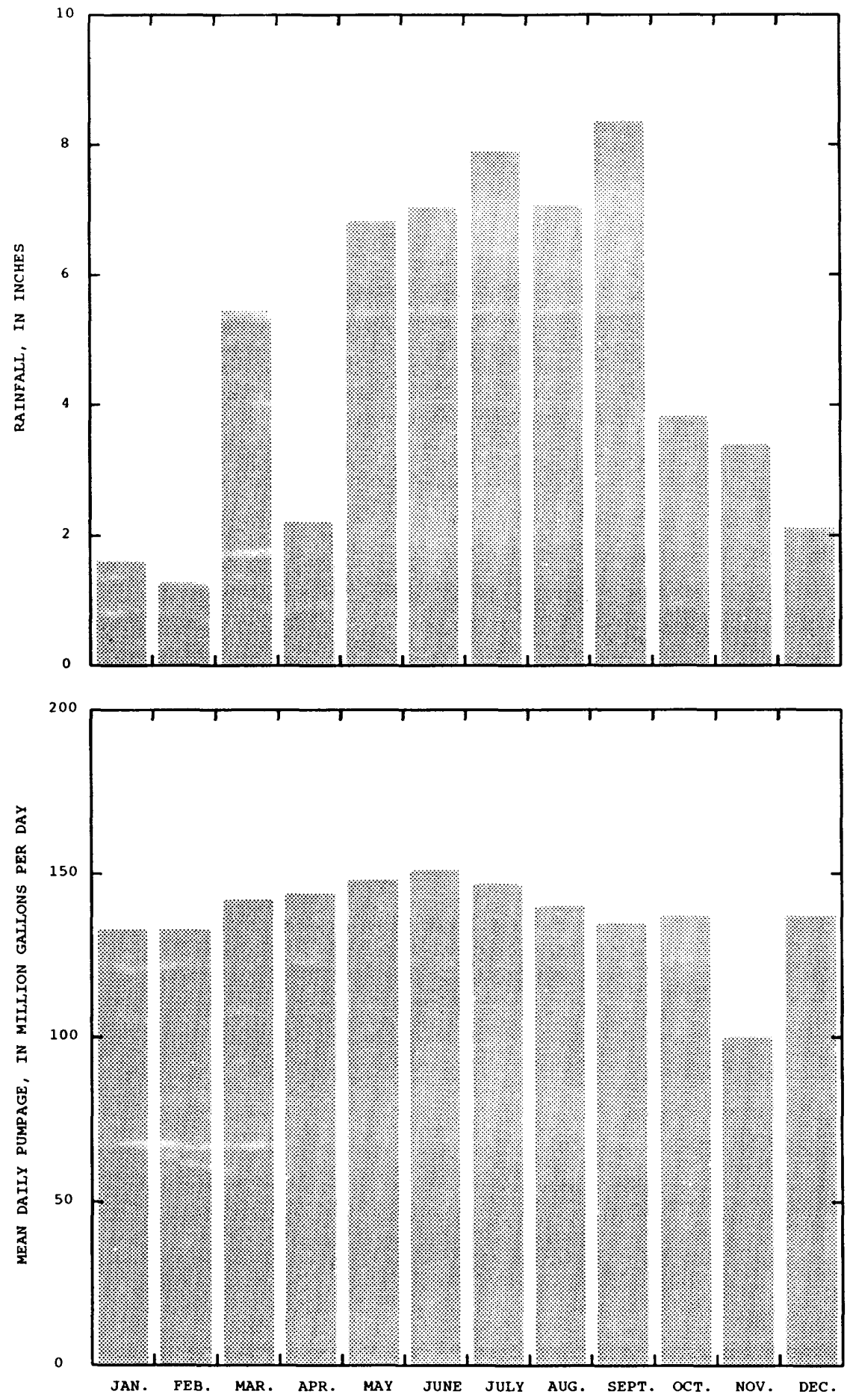

Figure 3. Average monthly rainfall at Miami International Airport and average mean daily pumpage by month from the Northwest Well Field, January 1984 to September 1987. 


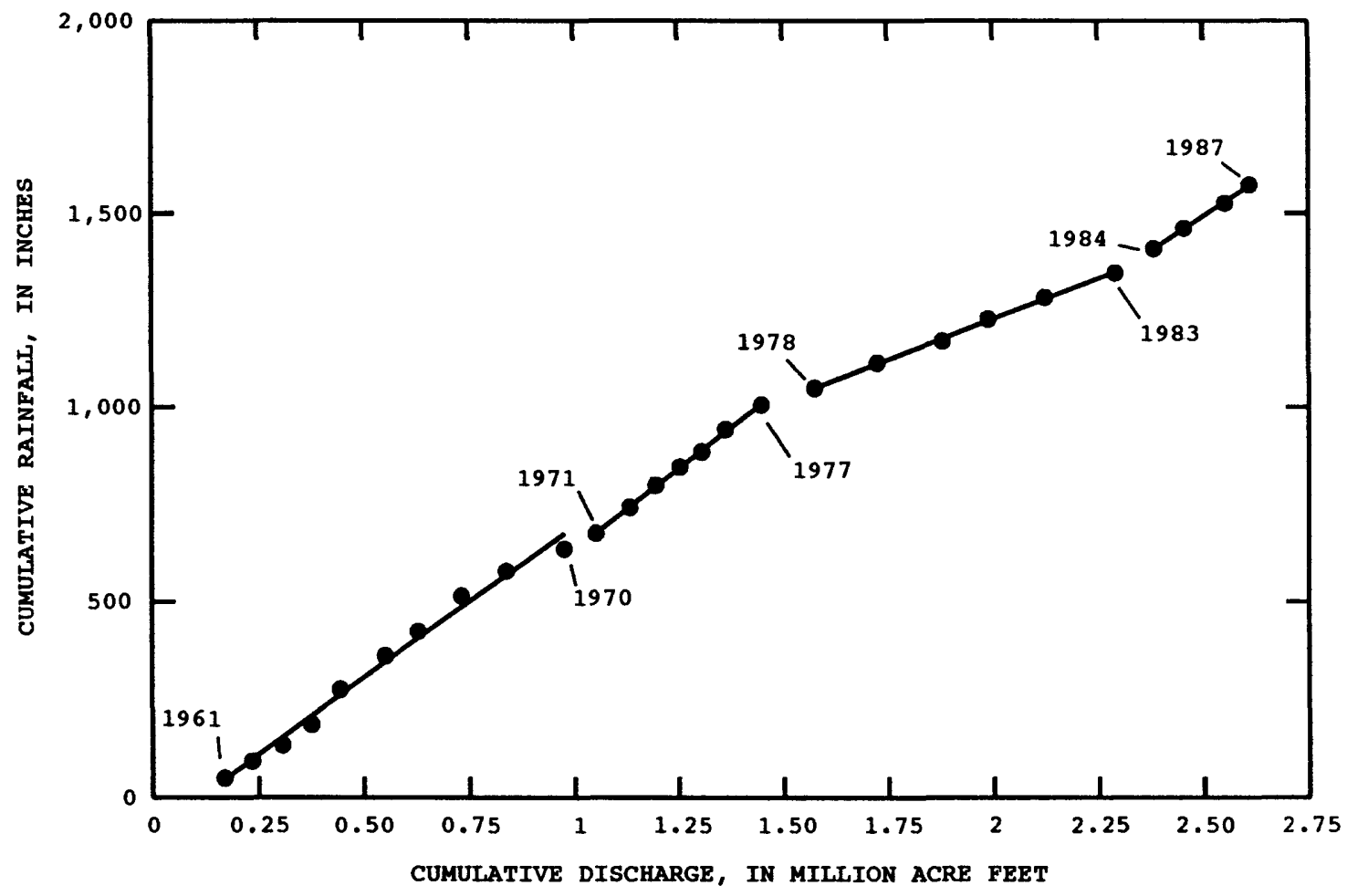

Figure 4. Relation between cumulative rainfall at Miami International Airport and cumulative discharge in Tamiami Canal at Coral Gables, 1961 to 1987.

\section{Water-Level Trends}

Water-level duration curves are used to analyze trends in water levels. These curves plot the percentage of time that a given water level was equaled or exceeded. A steep slope indicates a high variability in the water level. A large change in the slope of the duration curve toward a more negative slope generally occurs as the water level falls below land surface at the observation well.

Water-level data were analyzed for seven wells (G-968, G-972, G-974, G-975, G-976, G-1488, and G-3253) at the Northwest Well Field (fig. 1) for the period October 1960 to September 1987 (fig. 1). Hydrographs of daily maximum water levels for the stations are shown in figures 5 to 8. Using the breakpoint determined by the double-mass curve analysis of rainfall against canal discharge (fig. 4), four time periods were defined:

Period 1-Water years 1961 to 1970 (October through September) Period 2-Water years 1971 to 1977 (October through September) Period 3-Water years 1978 to 1983 (October through September) Period 4-Water years 1984 to 1987 (October through September)

\section{Background Conditions}

Well G-968, 5.5 miles from the Northwest Well Field on the west side of L-30 (fig. 1), is considered to represent background conditions. It is buffered from the influences of the well field by L-30 and the L-30 Canal. A hydrograph of daily maximum water levels in this well for the period October 1960 to September 1987 is shown in figure 5. The duration curves for this well show two separate water-level patterns (fig. 9). Water levels for periods 1 and 2 are about 1 foot below those for periods 3 and 4, which is an indication of the increased stages that have been maintained in the conservation area since the dry periods of the 1960's and 1970's. Water levels for periods 3 and 4 are almost identical, indicating no effect from the Northwest Well Field.

\section{Wells Outside the Cone of Depression}

Hydrographs for wells G-972, G-975, and G-1488 -all located outside the cone of depression of the Northwest Well Field-show no water-level trends other than seasonal fluctuations (figs. 5 and 6 ).

The duration curves for well G-972 show two significant differences in water levels over time (fig. 9). Water levels for period 1 are lower than those for the other three periods at the lower end of the curve. Water levels for period 2 are about 0.25 foot below those for periods 3 and 4 . These differences are possibly the result of the lower stages maintained in the conservation area as reflected by water levels at well G-968. 


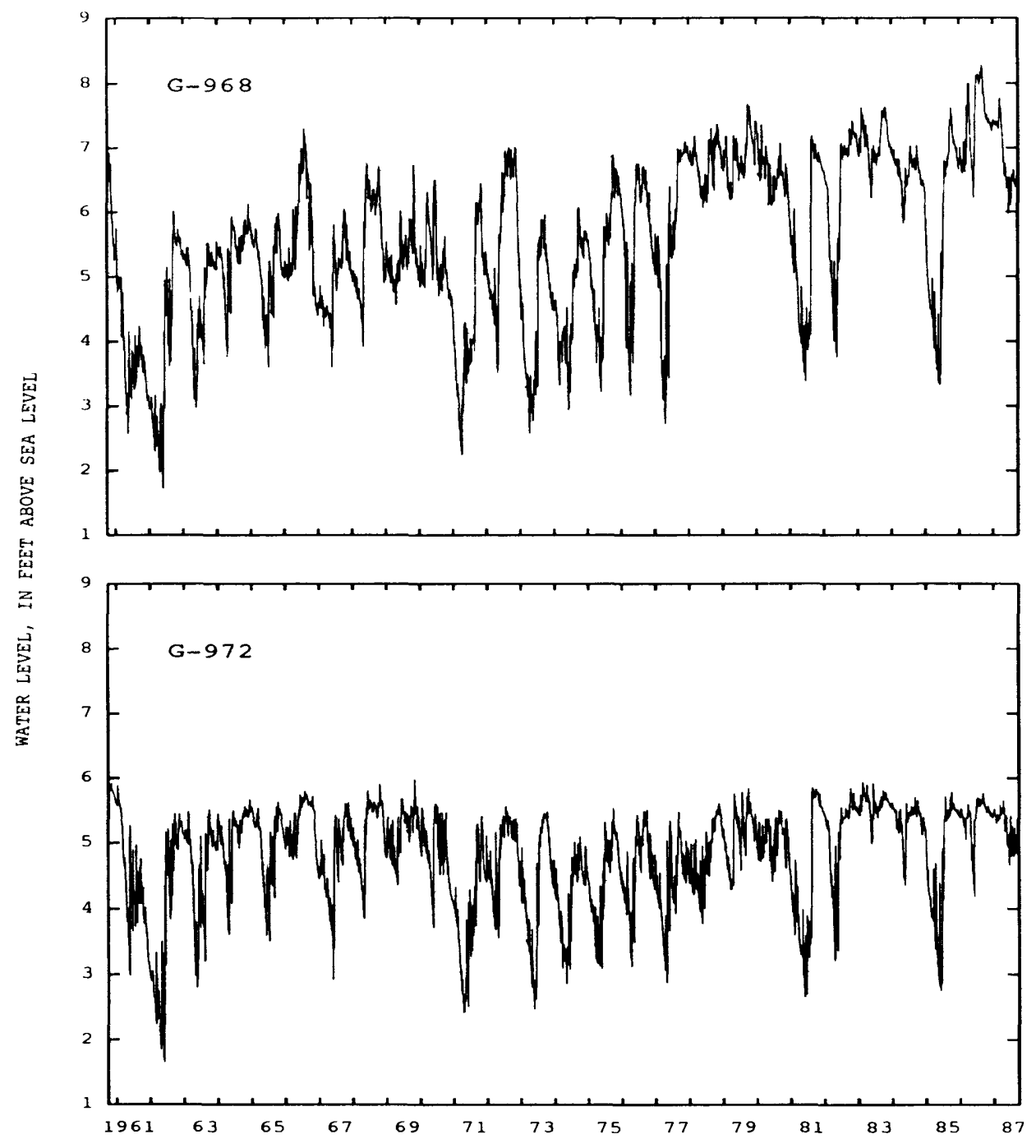

Figure 5. Daily maximum water levels in observation wells G-968 and G-972, October 1960 to September 1987.

The duration curves for well G-975 show only one significant difference in water levels (fig. 10). For period 1, water levels above land surface are about 0.5 to 2 feet higher than those for the other three periods. The change in the slope of the curve for period 1 occurs at about the same percentage as the curves for the other periods, but is about 0.5 foot higher. This may indicate a change in land-surface elevation, possibly due to subsidence of the peat soils during extended dry periods.

Well G-1488 was not drilled until 1969. Therefore, the duration curves for well G-1488 (fig. 10) only show data for periods 2,3 , and 4 . Water levels for these periods indicate little variation from one period to the next, as was the case at well G-975. In summary, water levels in wells G-972, G-975, and G-1488 showed no discernible effect from the Northwest Well Field.

\section{Wells Within the Cone of Depression}

Wells G-974, G-976, and G-3253 are located within the cone of depression of the Northwest Well Field (fig. 1). Hydrographs for these wells show generally lower water levels since the well field began operating in 1984 (figs. 7 and 8).

Water levels were collected at wells G-974 and G-976 for all four time periods. The duration curves for these two wells are similar (fig. 11). Water levels for periods 1 to 3 follow a similar pattern to those for the same periods at wells G-975 and G-1488 (fig. 10). Factors influencing water levels, such as rainfall and stage in the conservation area, were similar at all four wells during these time periods. During period 4, water levels for wells G-974 and G-976 were from about 0.5 to 1 foot below those for periods 2 and 3 , indicating some effect from the Northwest Well Field. 


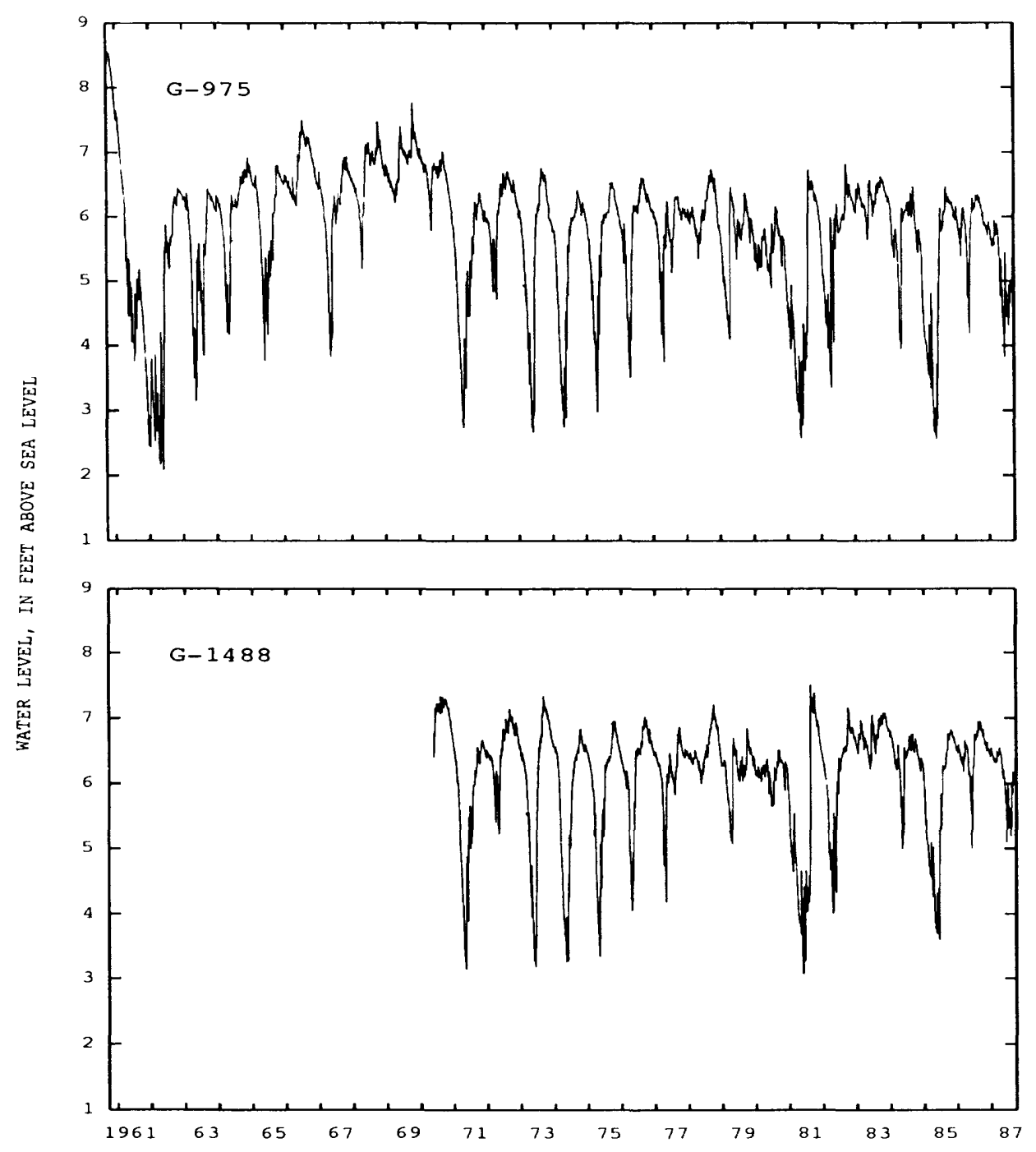

Figure 6. Daily maximum water levels in observation wells G-975 and G-1488, October 1960 to September 1987.

Well G-3253, in the center of the Northwest Well Field (fig. 1), has only one complete water year of data (October 1982 to September 1983) before the operation of the well field. The duration curve for this well shows that dry-season water levels are as much as 6 feet lower after the well field became operational (fig. 12).

\section{EFFECTS OF PUMPING ON WATER LEVELS IN THE WETLAND}

Since the completion of L-30 in 1952, the major emphasis of water management in the study area and in surrounding areas has been the maintenance of sufficiently high water levels to prevent saltwater intrusion in coastal well fields and to prevent draining of the remaining wetlands.
This has been accomplished mainly through the installation of salinity-control structures in canals near the coast and additional control structures and pumping stations in upgradient reaches of canals. Stages in the canal are the primary controlling criteria for the operation of these structures. For example, coastal structures are only opened when the upstream stage is above a specified level, reducing the potential for flooding in urban areas. These structures are closed most of the time, preventing the water levels near the canals from becoming too low and preventing saltwater from moving upstream with the tides.

Water-table maps from the 1940's (Parker and others, 1955 , p. 180-182) show the general direction of groundwater flow was to the east and northeast in the area east of the Dade-Broward Levee, except in the vicinity of the east-west canals (Pennsuco, Dressels, Northline, and Tamiami Canals). 


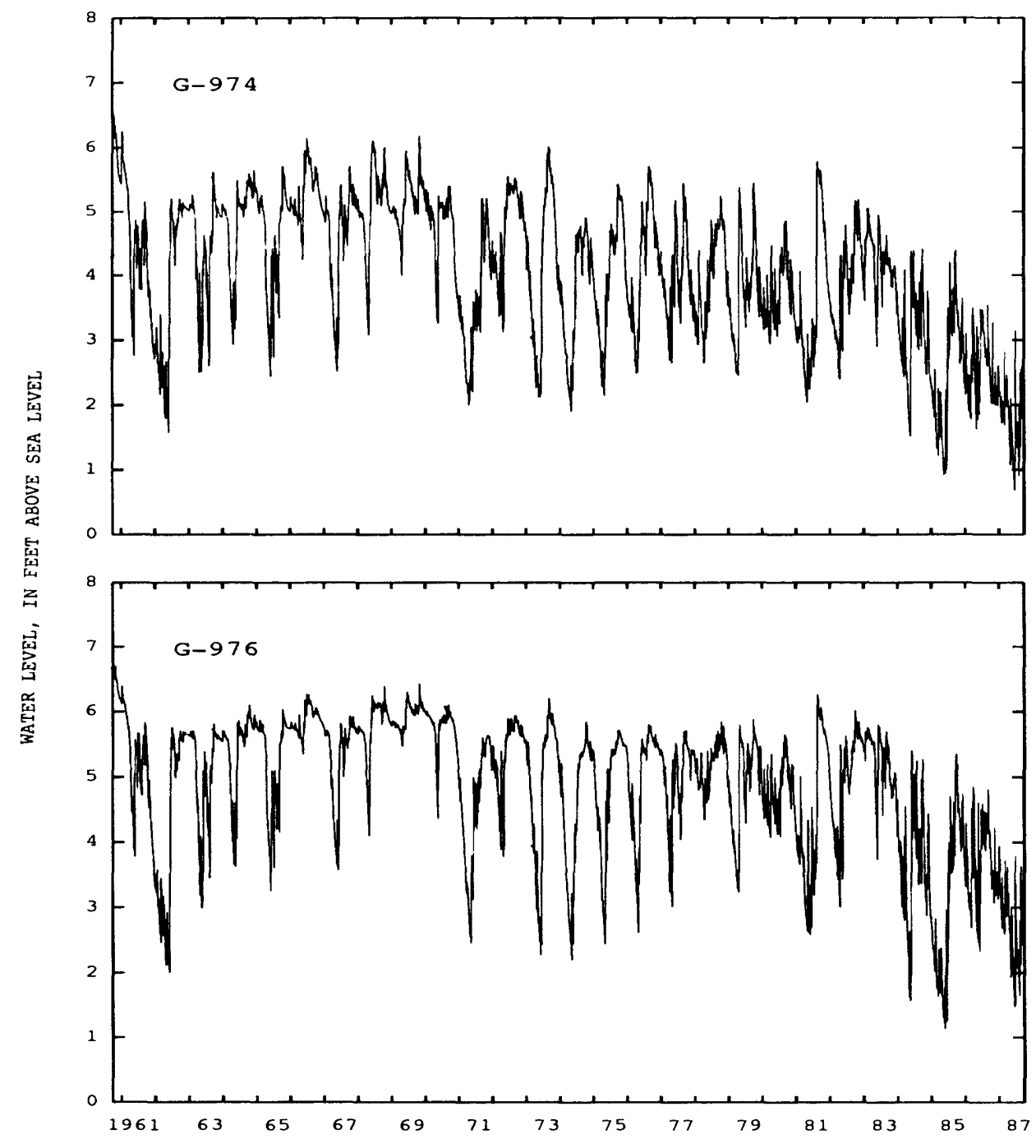

Figure 7. Daily maximum water levels in observation wells G-974 and G-976, October 1960 to September 1987.

During these periods, the canals behaved as drains, with ground water infiltrating the canals from both the north and south sides. This pattern still prevailed in 1979 (Ratzlaff, 1981a; 1981b) before the completion of the Northwest Well Field. Since the Northwest Well Field became operational, flow patterns west of the Dade-Broward Levee and north of the Pennsuco Canal have been relatively unaffected. However, east of the Dade-Broward Levee and south of the Pennsuco Canal, flow patterns have changed with ground water now moving toward the well field from the canals surrounding the well field (Klein, 1986a; 1986b).

An east-west profile (fig. 13) through the Northwest Well Field shows water levels at the end of both the wet season (October) and dry season (April) before and after the well field began pumping. These water levels are representative of typical maximum and minimum annual levels. Water levels in the center of the well field have declined 6 to 7 feet during both the wet and dry seasons since pumping began. At the eastern end of the profile, the decline in water levels is less than 1 foot. The western end of the profile shows a lower water level during the wet season after pumping began, but a higher water level during the dry season after pumping began. These water-level profiles each represent only a point in time, and such variations in water levels at the edges of the section may be due to short-term fluctuations in the water table. There are no available long-term water-level data on the eastern end of the'profile to determine if this variation is significant. Water levels at well G-975, 2 miles north of the western edge of the profile, showed no changes due to pumping at the well field. Thus, the apparent rise in dry-season water levels at the west end after pumping began is probably because of some anomalous condition in either April 1983 or April 1988 and is not significant. 


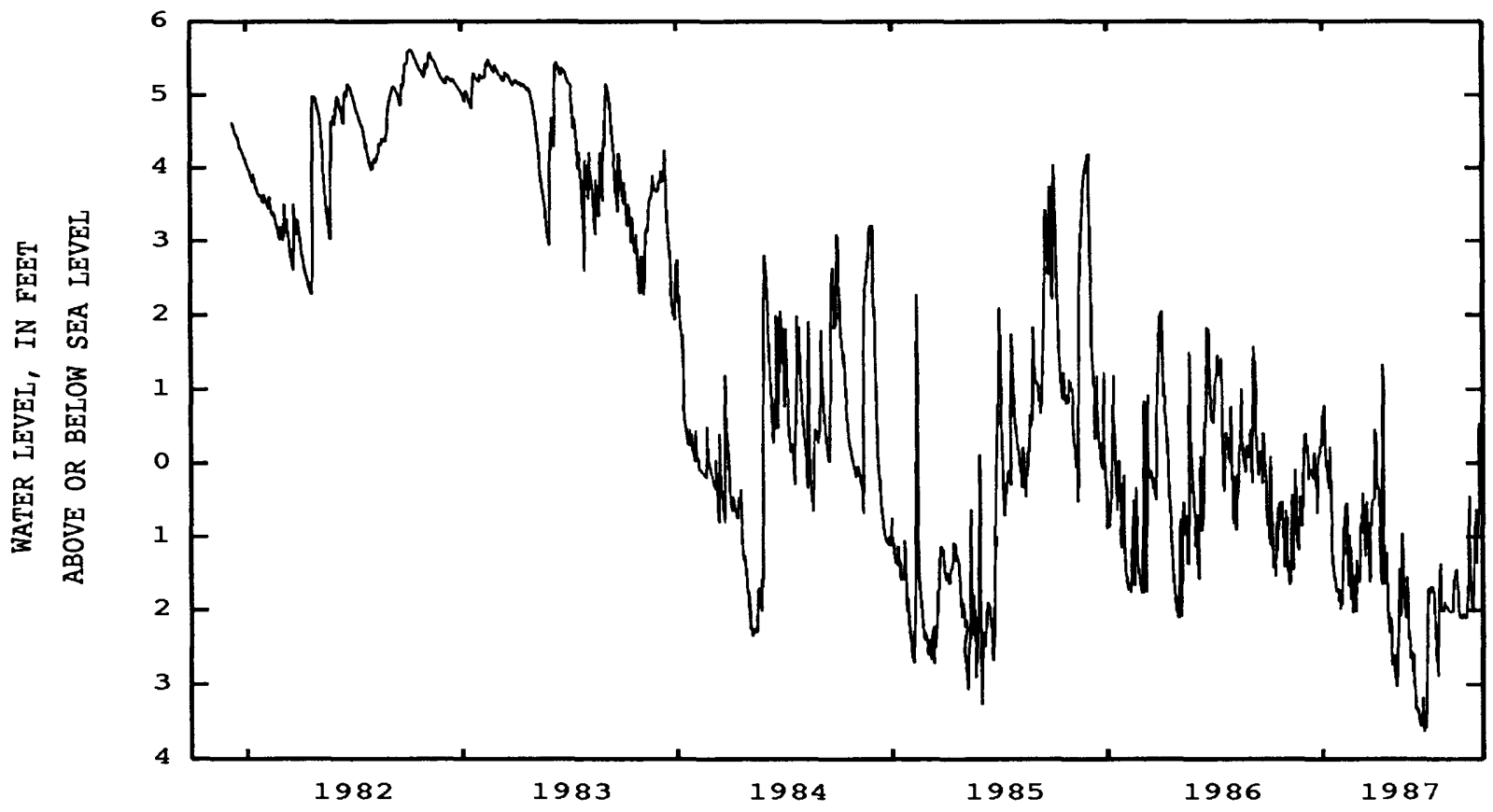

Figure 8. Daily maximum water levels in observation well G-3253, December 1981 to September 1987.

Since the Northwest Well Field began operating, water levels in three of the six wells in Area B have been below land surface nearly the entire time (figs. 9-12). Before 1984, water levels in all six wells were above land surface from 25 to 50 percent of the time. Since the well field began operating in 1984, water levels in well G-976 have been above land surface less than 1 percent of the time. In wells G-974 and G-3253, water levels have been below land surface since pumping began. Part of the wetlands region (fig. 1) no longer has water standing above land surface. This dewatered area encompasses about $10 \mathrm{mi}^{2}(15$ percent of the study area).
Surrounding the region that has been dewatered is another area where the duration of time in which water levels are above land surface has decreased. There are no longterm water-level monitoring wells in this area, but based on a comparison of the potentiometric surfaces (Ratzlaff, 1981a, 1981b; Klein, 1986a, 1986b), this area is nearly as large as the region that has been dewatered. Thus, the area surrounding the well field where water levels have been affected by pumping from the well field encompasses almost $20 \mathrm{mi}^{2}$ ( 30 percent of the study area). 


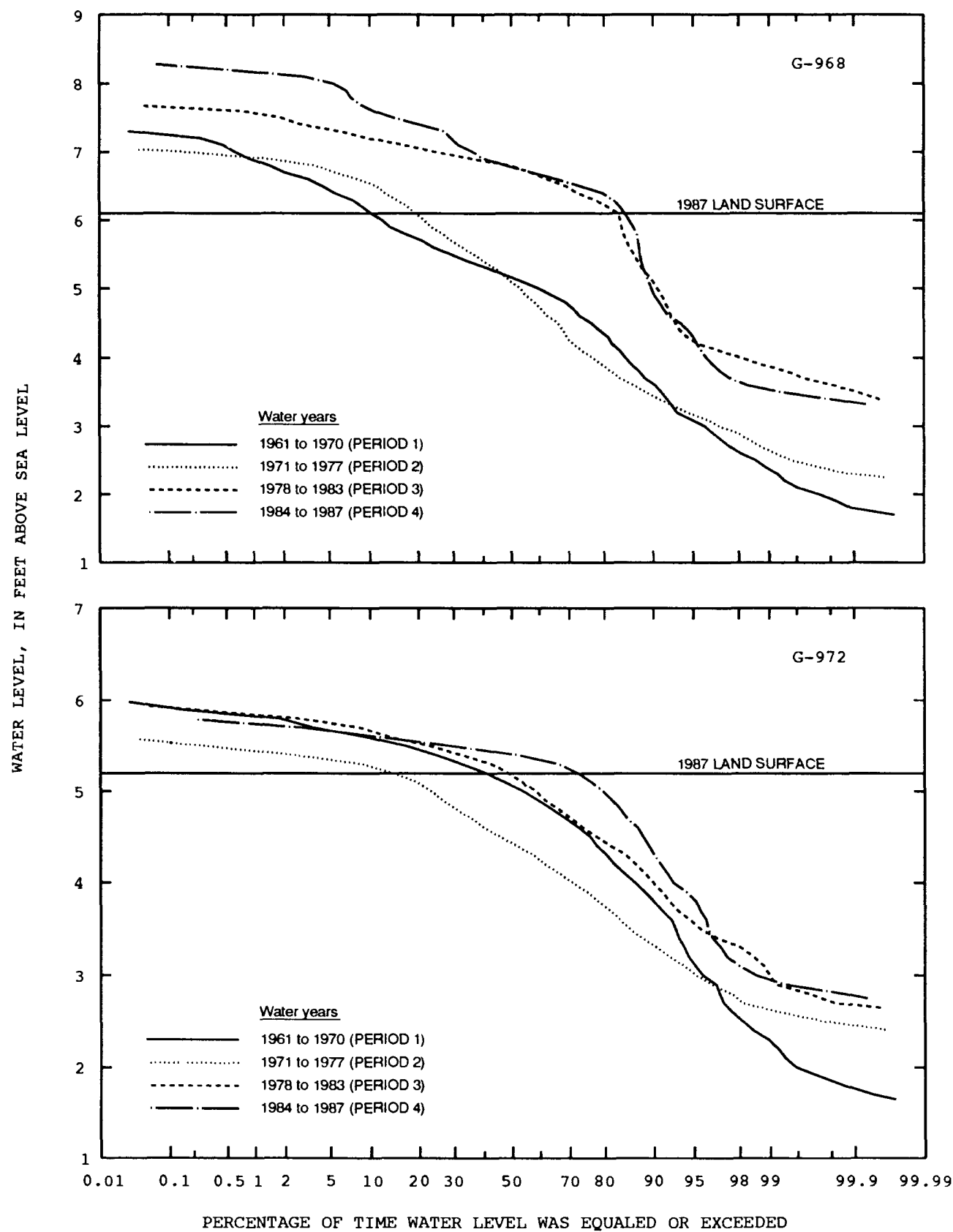

Figure 9. Water-level duration curves for wells G-968 and G-972. 


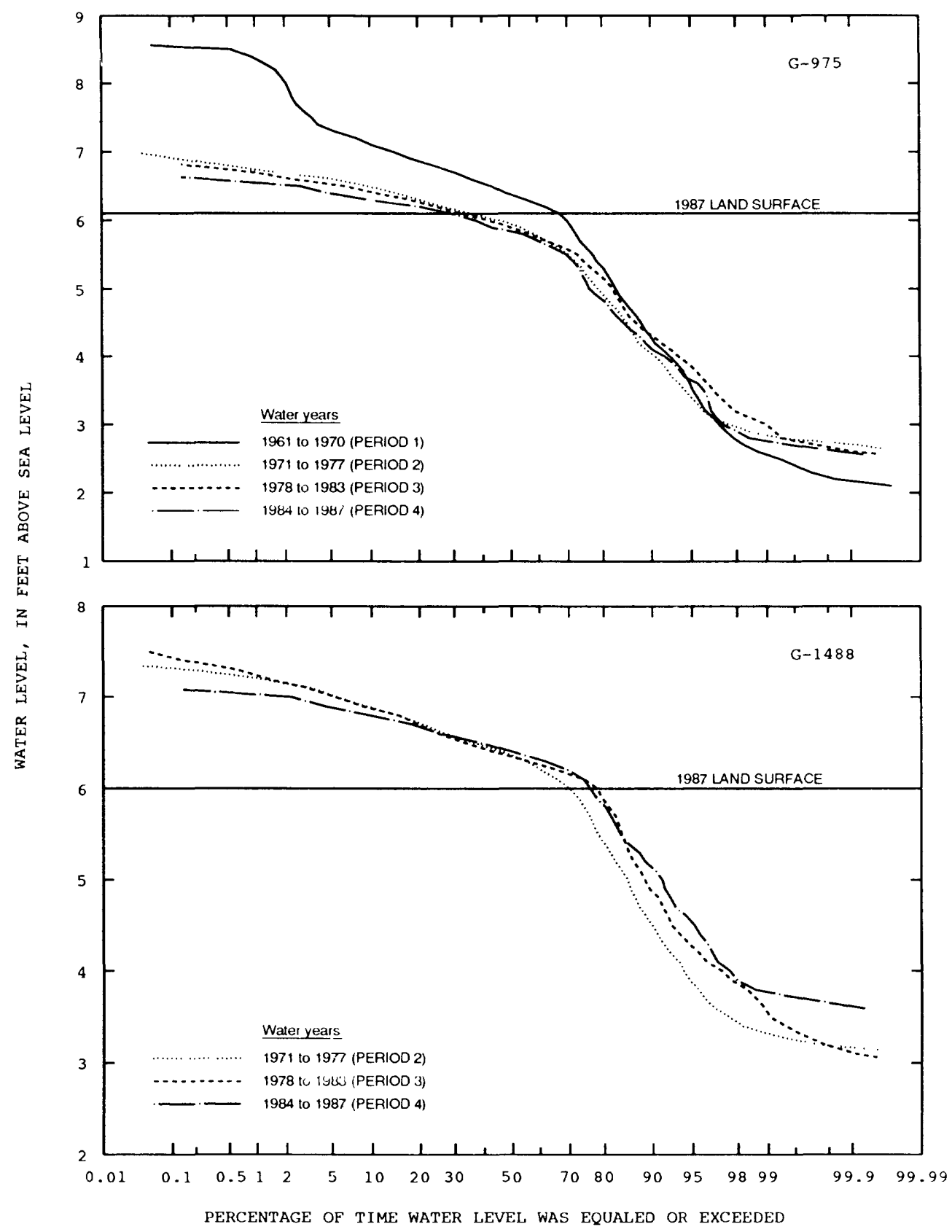

Figure 10. Water-level duration curves for wells G-975 and G-1488. 


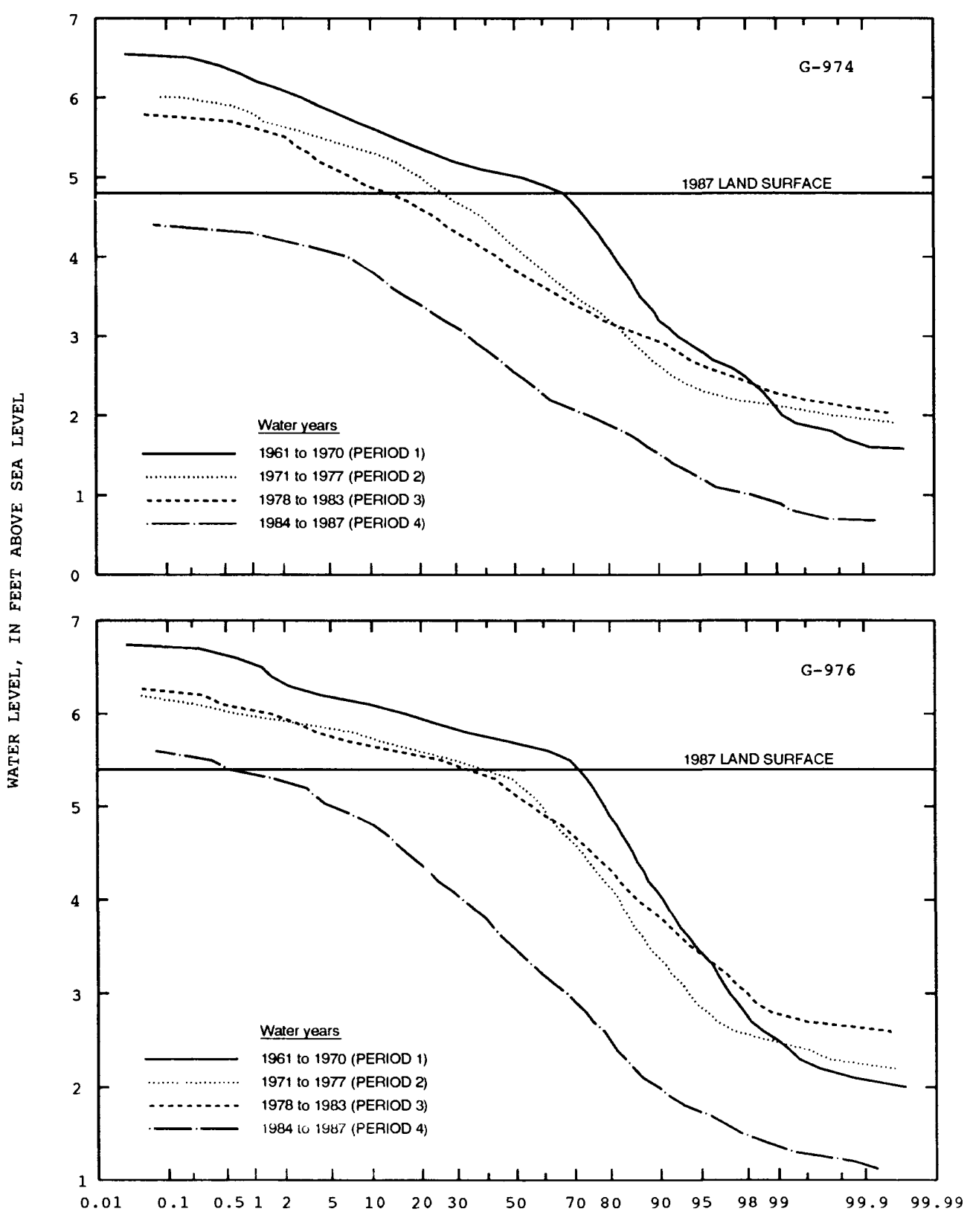

PERCENTAGE OF TIME WATER LEVEL WAS EQUALED OR EXCEEDED

Figure 11. Water-level duration curves for wells G-974 and G-976. 


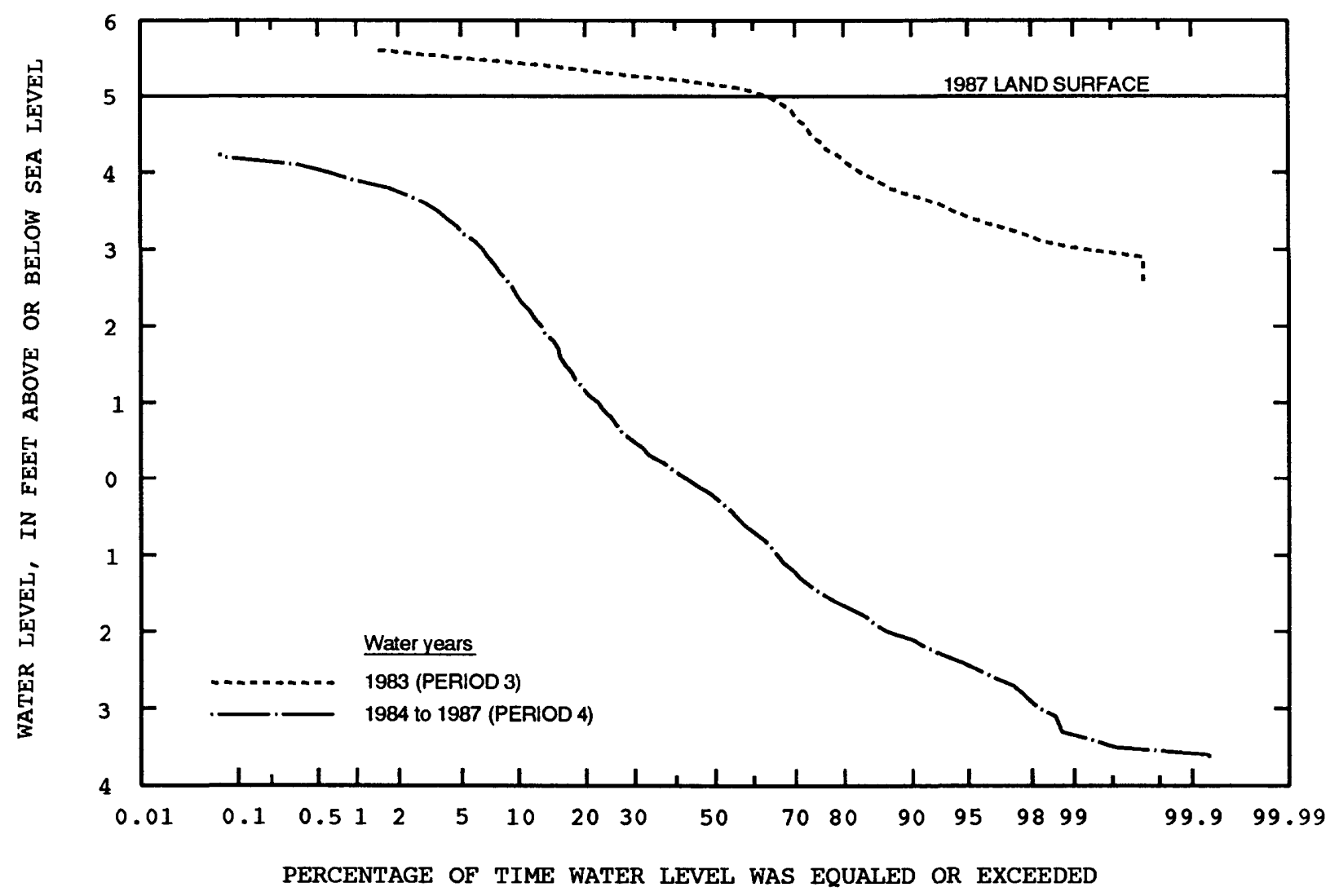

Figure 12. Water-level duration curves for well G-3253.

\section{SUMMARY}

Water-level duration curves and double-mass curves were used to determine the effects of water-management practices and of pumping from the Northwest Well Field on water levels in the vicinity of the well field. The doublemass curve relating cumulative rainfall and cumulative discharge of the Tamiami Canal at Coral Gables indicated changes in water-management practices beginning in 1971 and again in 1978. This curve also showed the decrease in discharge of the canal in May 1983 when the well field began pumping. The three breakpoints in the double-mass curve $(1970,1977,1983)$ were used to determine the four time periods used for the duration-curve analysis. Analysis of the duration curves indicated that water levels at three of the six monitoring wells in the study area were affected by well-field pumping. In the center of the well field, water levels have been lowered by more than 6 feet in both wet and dry seasons.

Water levels have been affected by well-field pumping in an area encompassing almost $20 \mathrm{mi}^{2}$ (30 percent of study area) around the well field. This region is divided into two almost equal parts. The first part is the region within and immediately around the well field where the wetland has been dewatered and the land is now dry. Surrounding this region is an area where water levels are not below land surface all of the time but have been lowered by pumping. The area dewatered by pumping at the well field is about $10 \mathrm{mi}^{2}$ (15 percent of the study area) and is no longer considered a wetland.

\section{REFERENCES CITED}

Causaras, C.R., 1987, Geology of the surficial aquifer system, Dade County, Florida: U.S. Geological Survey Water-Resources Investigations Report 86-4126, 240 p., 3 sheets.

Fish, J.E., and Stewart, Mark, in press, Hydrogeology of the surficial aquifer system, Dade County, Florida: U.S. Geological Survey Water-Resources Investigations Report 90-4108.

Hofstetter, R.H., and Sonenshein, R.S., 1990, Vegetative changes in a wetland in the vicinity of a well field, Dade County, Florida: U.S. Geological Survey Water-Resources Investigations Report 89-4155, 16 p.

Jordan, C.L., 1984, Florida's weather and climate: Implications for water, in Fernald, E.A., and Patton, D.J., eds., Water resources atlas of Florida: Tallahassee, Florida State University, Institute of Science and Public Affairs, p. 18-35. 


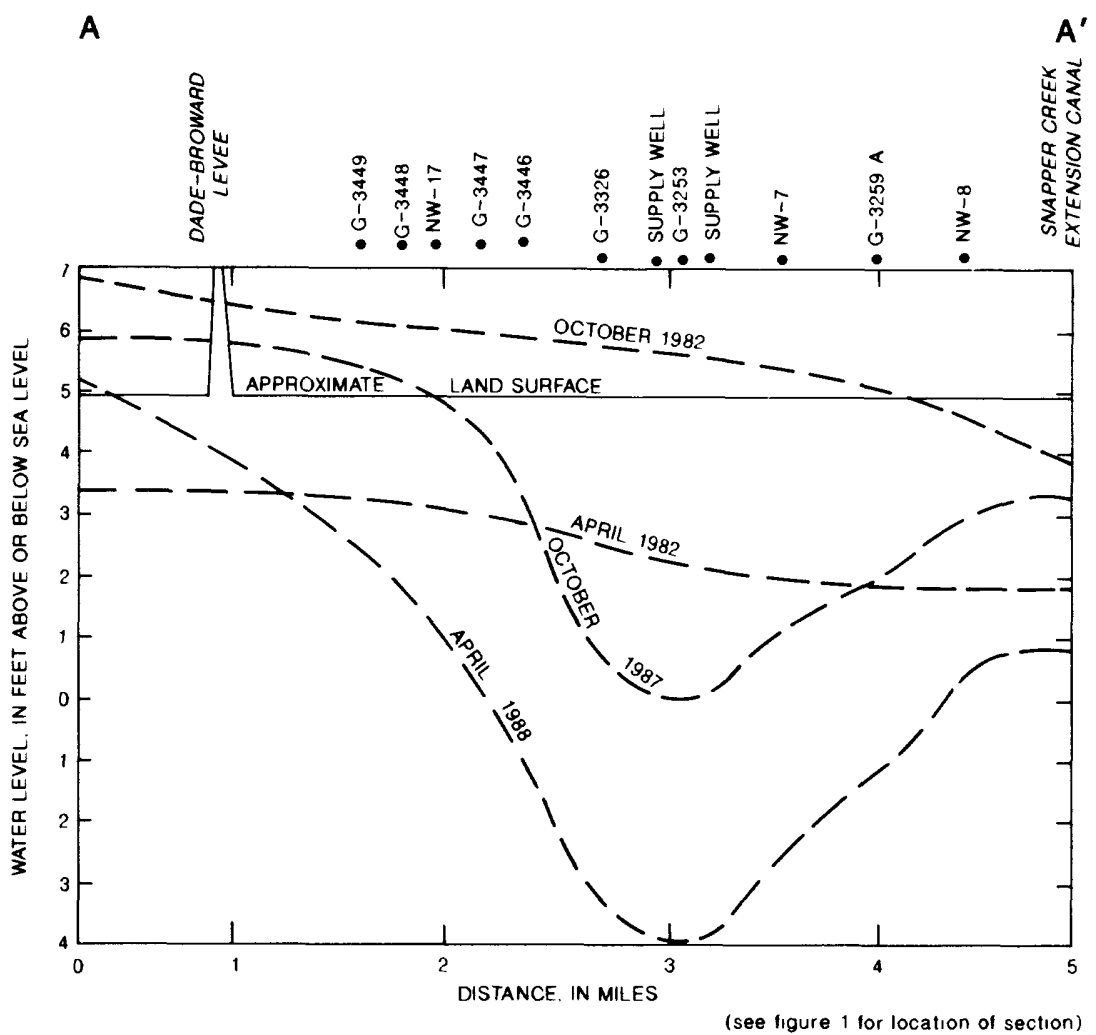

Figure 13. Section $A-A^{\prime}$ showing water levels for April 1982, October 1982 , October 1987, and April 1988.

Klein, Howard, 1986a, Potentiometric surface of the Biscayne aquifer, Northwest Well Field, Dade County, Florida, May 24, 1984: U.S. Geological Survey Open-File Report 86-60, 1 sheet.

1986b, Potentiometric surface of the Biscayne aquifer, Northwest Well Field, Dade County, Florida, October 16, 1984: U.S. Geological Survey Open-File Report 86-59, 1 sheet.

Klein, Howard, Armbruster, J.T., McPherson, B.F., and Freiberg, H.J., 1975, Water and the south Florida environment: U.S. Geological Survey Water-Resources Investigations Report 24-75, 165 p.

Klein, Howard, and Sherwood, C.B., 1961, Hydrologic conditions in the vicinity of levee 30, northern Dade County, Florida: Florida Geological Survey Report of Investigations 24, part 1, 24 p.

Kohout, F.A., and Hartwell, J.H., 1967, Hydrologic effects of Area B flood control plan of urbanization of Dade County, Florida: Florida Geological Survey Report of Investigations 47, 61 p.

Labowski, J.L., 1988, Geology, hydrology, and water-monitoring program, Northwest Well Field protection area: Metropolitan Dade County, Florida Department of Environmental Resources Management Technical Report 88-3, 53 p.

Leach, S.D., Klein, Howard, and Hampton, E.R., 1972, Hydrologic effects of water control and management of southeastern Florida: Florida Bureau of Geology Report of Investigations 60, $115 \mathrm{p}$.
National Oceanic and Atmospheric Administration, 1986, Surface land daily cooperative summary of the day: National Climatic Data Center Technical Document 3200, 23 p.

Parker, G.G., Ferguson, G.E., Love, S.K., and others, 1955, Water resources of southeastern Florida: U.S. Geological Survey Water-Supply Paper 1255,965 p.

Ratzlaff, K.W., 1981a, Altitude of water table, Biscayne aquifer, Dade County, Florida, March 1979: U.S. Geological Survey Open-File Report 81-647, 1 sheet.

1981b, Altitude of water table, Biscayne aquifer, Dade County, Florida, October 1979: U.S. Geological Survey Open-File Report 81-807, 1 sheet.

Searcy, J.K., and Hardison, C.H., 1960, Manual of hydrology: Part 1.-General surface-water techniques, double-mass curves: U.S. Geological Survey Water-Supply Paper 1541-B, $66 \mathrm{p}$.

Stallman, R.W., 1956, Preliminary findings on ground-water conditions relative to Area B flood-control plans, Miami, Florida: U.S. Geological Survey Open-File Report FL-56001, 42 p.

U.S. Army Corps of Engineers, 1954, Design memorandum, hydrology, and hydraulic design, canals in greater Miami area (C-2 through C-9) (revised): Central and South Florida Project for Flood Control and Other Purposes: Part V.-Coastal areas south of St. Lucie Canal: Supplement 12: Jacksonville, Fla., U.S. Army Corps of Engineers, 157 p., 104 pls. 